\title{
THE TRANSITION TO ENGLISH TEACHING: INFLUENCES AND CONSIDERATIONS FOR FOREIGN LANGUAGE EDUCATION AND LANGUAGE PLANNING
}

\author{
Tran Thi Hao* \\ School of Humanities, Languages and Social Science, Griffith University, \\ 170 Kessels Rd, Queensland, Australia
}

Received 27 April 2018

Revised 25 September 2018; Accepted 28 September 2018

\begin{abstract}
Language policy enactment processes are complex, confounded by varied forces and interests, and shaped through negotiations, interpretations and compromise. Working from this perspective, this article examines the transition process of foreign language teachers from teaching other languages to teaching English, and the influences of this process on general foreign language education and language planning. In Vietnam, even though the shift to English teaching from other languages has been noted as a phenomenon, its process with grass-roots changes and potential influences on foreign language policy enactments in the country have not been specifically examined. By employing a case study approach, this article explores the transition process at An Nam University (pseudonym), one of the universities undergoing the transition process. Drawn from a document, a preliminary survey, interviews with both teachers and leaders and observations, my study concludes that the transition process has an important role with various influences on different aspects in foreign language education in the university and in Vietnam. The study aims to provide fundamental pointers to current language policy implementation in the country as well as to other contexts undergoing similar changes.

Keywords: foreign language education, transition (“chuyển đổi”), Vietnam, English teachers, language policy planning

\section{Introduction}

Policy processes have been considered to be complex, confounded by varied forces and interests and shaped through negotiations, interpretations and compromise (Ball, 1994; Bowe, Ball \& Gold, 1992; Gornitzka, Kogan \& Amaral, 2005; Ozga, 2000, Reynolds \& Saunders, 1987; Sin, 2014; Trowler, 2002; Trowler, Saunders \& Knight, 2004). The

*Tel.: +61-450148387

Email: haotran203@gmail.com

implementation of language policies is claimed to be a policy enactment rather than a linear implementation process (Ball, Maguire \& Braun, 2012). Singh, Thomas and Harris (2013) also emphasise the complexity, nuance and multidirectionality of policy enactment processes. The exploration of such processes is significant to understanding the complexity of policy enactments in this research field in general and in Vietnam in particular.

In Vietnam, even though many foreign language policies and educational changes have been promulgated, the complex
\end{abstract}


enactment process of these policies, especially at grass-roots level, has lacked adequate attention. In particular, given that the transition from teaching other languages to teaching English, known here as the transition process, has been noted as a phenomenon in different studies alongside changes in foreign language education policy (Hoang, Nguyen \& Hoang, 2006; Nguyen, 2011; Nguyen, 2012; Nguyen \& Mai, 2015; Tran, 2015), it has not been specifically examined. Working from the perspective that policy and educational changes involve complex aspects in their implementation, this article explores this transition process of a group of teachers from teaching Chinese, French and Russian to teaching English, hereafter referred to as transitioned teachers or TTs at An Nam University.

\section{Language policy enactments}

According to Ball (1994), the process of introducing and enacting policies was complex, rather than a linear top-down perspective. $\mathrm{He}$ said, "policies do not normally tell you what to do, they create circumstances in which the range of options available in deciding what to do are narrowed or changed, or particular goals or outcomes are set" (Ball, 1994, p. 19). As opposed to the unidirectionality implied in "implementation", many scholars have pointed out the complexity, nuances and multidirectionality of language policy introduction and enactments, as well as acknowledging the disparity between formal policy decisions and practice (Ball, 1994; Bowe et al., 1992; Gornitzka et al., 2005; Ozga, 2000; Reynolds \& Saunders, 1987; Trowler, 2002; Trowler et al., 2004).

In light of policy enactment, the focus on language policy has moved from the substance of policy itself to the practices in which policy becomes implicated and to which it contributes positively or negatively (Heimans, 2014). In other words, it is not just the question of knowing what policy is as a static object but more importantly and more concerningly, of knowing about the messiness and unpredictability of what people do in response to the policy. This article explores the transition process from teaching other foreign languages to English teaching as a result of educational and political changes based on this overall approach of language policy enactment.

\section{Language policy and planning and teachers' roles}

In an overview volume on the field of language policy and planning (LPP), Kaplan and Baldauf (1997) proposed that language planning occurred at several levels, the macro, the meso and the micro. It was argued that when applied linguists think of language planning, they normally consider it in terms of large-scale, usually national, planning. This process is often undertaken by governments and is meant to influence and/or change practices within a society. The importance of micro-level language LPP or what happens at schools or university with the involvement of teachers, has over time however been widely recognised. Many studies have highlighted the need to involve people at all levels including teachers with their important role in the language policy making process (Baldauf, 2012; Campbell, 2012; Datnow, 2012; Hamid \& Nguyen, 2016; Liddicoat \& Baldauf, 2008; Ollerhead \& Ollerhead, 2010; Priestley, Edwards, Priestley \& Miller, 2012; Ramanathan \& Morgan, 2007; Vahasantanen, 2015).

Notably, teachers have been broadly identified as "central agents in language 
policy development" (Baldauf, 2006, p. 54). Teachers from different backgrounds may be differently involved in change processes and policy enactments, and individual agency "may compromise the impact of a national language policy" (Baldauf, 2012, p. 240). In this article, the exploration of the TTs' experiences in line with the transition will thus significantly contribute to understanding the influences of dynamic educational changes in Vietnam, particularly the transition, regarding general foreign language education. Findings about the transition at An Nam university and its potential influences on the current policy and education context at the university and in Vietnam as a whole may well contribute important pointers to current foreign language education, especially teacher education, and language policy in the country, as well as to other contexts experiencing similar language shift.

In response to policy promulgation in Vietnam, several studies have investigated teachers' responses but have been mainly focused at primary level (Hamid \& Nguyen, 2016; Mai, 2014; Phyak \& Bui, 2016). None of the studies has explored the transition process specifically, or more importantly, the experiences of the TTs combined with the influences of this process on general foreign language education in Vietnam. Acknowledging the potential contribution of the transition and the TTs in foreign language education in Vietnam, the current article aims to fill these gaps by addressing the following research questions:

1. How did the transition from teaching other foreign languages to English happen in Vietnam?

2. How has this transition influenced foreign language education in Vietnam?

\section{Research context and methodology}

This article employs a case study approach, which is closely associated with natural inquiry (Merriam, 1998; Stake, 1995; Yin, 1984), to address the above research questions. Previously offering different foreign languages including Chinese, Russian and French, and currently mainly English, An Nam University, which is explored in this study, is the embodiment of language change and shift in Vietnam. The exploration of this case works as a mirror for understanding other universities and institutions experiencing a similar change. My research role as an insider, a tertiary lecturer in Vietnam, and an outsider researcher, not a TT, allowed me to explore indepth insights of the case, avoid subjectivity and build up strong credibility for the research (Unluer, 2012).

A faculty document, a preliminary survey, and more importantly, 20 semi-structured interviews with 20 TTs and two interviews with two leaders of the faculty and the university, as well as observations from Zalo, a popular online communication tool in Vietnam and widely used in the faculty, were all collected and analysed. "Kỷ yếu khoa" (The faculty's development history document), which was publicly shared in the faculty, was firstly collected and analysed to better understand the case. A preliminary survey was then sent to the participants via email after they agreed to take part in the study. The surveys constructed an overall demographic profile of the participants together with general themes to be further explored in interviews and complemented by observations. Interviews were conducted at times convenient for the participants and observation field notes were gathered after the researcher received the participants' consent forms. This triangulation of data collection allowed for the strength and 
in-depth of the findings' insights regarding the research questions as well as built the trustworthiness of the data (Glense, 2006).

Content analysis was employed as an analytical approach by extracting a set of characteristics from a text (Franzosi, 2004) and making valid inferences (Weber, 1990). This allowed me to explore the TTs' transition as well as its influences on foreign language education authentically. All of the data were analysed, transcribed and coded in the original Vietnamese, and only the coded themes were translated to English to be reported.

\section{Findings and discussion}

The two research questions are addressed and discussed in this section through findings and in light of the literature. The exploration of the transitions happening at An Nam University and the discussions in accordance with a general language shift in the Vietnamese context will firstly be presented. The influences of these transitions on foreign language education at the university and in the country will then be delineated.

5.1. Research question 1: How did the transition from teaching other foreign languages to teaching English happen in Vietnam?

An Nam University witnessed two transitions in line with changes in the national language policies. These include the transition from teaching Russian to teaching English in the 1990s, and from teaching Chinese, French and Russian to teaching English since 2008. Based on "Kỷ yếu Khoa", Table 1 presents the language education development from the university's formation and delineates the two transitions in the university.

Table 1. Languages development history at the university and the transition

\begin{tabular}{|c|c|c|}
\hline Time & The development history of the case & The consequent transition \\
\hline Before 1990s & $\begin{array}{l}\text { The formation of An Nam University } \\
\text { Only Russian teachers to teach Russian to all } \\
\text { students at the university }\end{array}$ & \\
\hline \multirow[b]{2}{*}{ From 1990s } & $\begin{array}{l}\text { Expansion of the Foreign Languages Branch } \\
\text { of the university with four divisions: French, } \\
\text { Russian, Chinese and English. }\end{array}$ & \multirow{2}{*}{$\begin{array}{c}\text { The first transition: A group } \\
\text { of teachers transitioned from } \\
\text { teaching Russian to teaching } \\
\text { English }\end{array}$} \\
\hline & $\begin{array}{l}\text { The establishment of the Foreign Languages } \\
\text { Faculty: Training pre-service English language } \\
\text { teachers and teaching other languages including } \\
\text { French, Russian and Chinese to students of other } \\
\text { majors in the university. }\end{array}$ & \\
\hline Before 2010 & $\begin{array}{l}\text { Closure of French language teachers' major. } \\
\text { French teachers only teach French as a second } \\
\text { foreign language for English students. } \\
\text { Offering English as the only foreign language } \\
\text { for students of other majors in the university. }\end{array}$ & $\begin{array}{c}\text { The second transition: } \\
\text { Teachers of Chinese, } \\
\text { Russian and French started } \\
\text { to transition from teaching } \\
\text { these languages to teaching } \\
\text { English }\end{array}$ \\
\hline
\end{tabular}




\subsubsection{The two transitions and transitioned} teachers at An Nam University

The first transition that occurred at An Nam University witnessed the transition of Russian teachers to teaching English during the 1990s. As delineated in "Kỷ yếu Khoa", at the time of An Nam University's establishment until the early 1980s, Russian was the important foreign language taught and learnt at the university. Conversely, during the 1960s to 1980s, English was not as popular as French and Russian and was not introduced or taught at the university. English lecturers, as noted in this document, only worked in the science research laboratory to translate documents, and did not teach. However, from the 1990s, the university started to include English and Chinese in its teaching program. Especially, with the establishment of the Foreign Languages Faculty, the faculty set its aims of training pre-service Englishmajor language teachers and teaching other languages for students of other majors in the university. During this time, with the shortage of teachers in English following its exponential development in Vietnam, together with signs of the downgrading of Russian in the country, a group of Russian teachers decided to study and teach English. This formed the first transition in the university.

The second transition at the university involved the cases of not only Russian teachers but also Chinese and French teachers in line with the change at the university from a yearly-based to a credit-based education system. Before 2008, despite the continuing development of English in Vietnam in general and at An Nam University in particular since Doi moi (1986) (Vietnam's reform), Chinese, Russian and French were still taught at An Nam University for students of other majors. Under the yearly-based education system, the university decided which foreign language would be taught by which faculty. For example, students whose majors were Literature, History or Geography would study Chinese as the required foreign language, whereas the Maths, Physics and Chemistry group and English major students would study Russian and French respectively. However, following the national educational trend, An Nam University changed from a yearly-based system to a credit-based system. Following this change, the university chose English as the only required foreign language to be taught at university for all majors, and French as the second required foreign language only for English major students. Consequently, Russian and Chinese teachers had no official classes at An Nam University. Additionally, not long after this, the Foreign Languages Faculty closed the French teacher training major, which had been offered, and only maintained English majors. French teachers thus had only a limited number of classes for English major students in the Foreign Languages Faculty. As a result of these changes, the teachers of Russian, Chinese and French in the faculty decided to transition to teaching English. This formed the second transition of language teaching in the university.

Drawn from these two transitions, 20 TTs took part in this study. Through preliminary surveys, Table 2 provides basic demographic profile of these TTs. The names of TTs 1-20 are all pseudonyms, and are arranged in the table according to the language they used to teach, namely Chinese, Russian and French, or their first foreign language. Among these TTs, TTs $7,8,9$ belong to the first transition, while the remainder belongs to the second transition. Chinese TTs are from TT 1 to TT 4, Russian from TT 5 to TT 9, and French from TT 10 to TT 20. Five TTs of this group (TTs 5, 7, 8, $9,10)$ studied English at a national university 
in the capital of Vietnam. The others studied English in an in-service training course offered by An Nam University. When they finished their study and achieved a BA degree in English, they could officially change to teaching English. It took some teachers only two years in this process but up to four years for others.

Table 2. The transitioned teachers' demographic data

\begin{tabular}{|c|c|c|c|c|c|c|}
\hline \multirow{2}{*}{ Name } & $\begin{array}{c}\text { First } \\
\text { foreign } \\
\text { language }\end{array}$ & \multicolumn{2}{|c|}{$\begin{array}{c}\text { Teaching experience } \\
\text { (years) }\end{array}$} & \multicolumn{2}{c|}{ Degree } & $\begin{array}{c}\text { Language(s) } \\
\text { currently } \\
\text { teaching }\end{array}$ \\
\cline { 2 - 7 } & & $\begin{array}{c}\text { First } \\
\text { foreign } \\
\text { language }\end{array}$ & English & $\begin{array}{c}\text { First } \\
\text { foreign } \\
\text { language }\end{array}$ & English & \\
\hline TT 1 & Chinese & $>10$ & $<5$ & BA & MA & English/ Chinese \\
\hline TT 2 & Chinese & $5-10$ & $5-10$ & BA & MA & English \\
\hline TT 3 & Chinese & $5-10$ & $5-10$ & BA & MA & English/ Chinese \\
\hline TT 4 & Chinese & $5-10$ & $<5$ & MA & BA & English \\
\hline TT 5 & Russian & $<5$ & $5-10$ & MA & MA & English \\
\hline TT 6 & Russian & $<5$ & $5-10$ & BA & MA & English \\
\hline TT 7 & Russian & $>10$ & $>10$ & MA & BA & English \\
\hline TT 8 & Russian & $>10$ & $>10$ & MA & MA & English \\
\hline TT 9 & Russian & $5-10$ & $>10$ & PhD & BA & English \\
\hline TT 10 & French & $5-10$ & $5-10$ & MA & $\begin{array}{c}\text { PhD } \\
\text { candidate }\end{array}$ & English \\
\hline TT 11 & French & $5-10$ & $5-10$ & BA & MA & English/ French \\
\hline TT 12 & French & $5-10$ & $5-10$ & BA & MA & English \\
\hline TT 13 & French & $>10$ & $<5$ & MA & BA & English/ French \\
\hline TT 14 & French & $>10$ & $5-10$ & MA & BA & English/ French \\
\hline TT 15 & French & $>10$ & $5-10$ & MA & BA & English/ French \\
\hline TT 16 & French & $5-10$ & $5-10$ & MA & BA & English \\
\hline TT 17 & French & $>10$ & $5-10$ & MA & BA & English/French \\
\hline TT 18 & French & $>10$ & $5-10$ & MA & BA & English/French \\
\hline TT 19 & French & $>10$ & $5-10$ & MA & BA & English/ French \\
\hline TT 20 & French & $5-10$ & $<5$ & PhD & BA & English/ French \\
\hline
\end{tabular}

\subsubsection{Reflecting language shift in Vietnam}

It is notable that the transitions happening at An Nam University were in tandem with changes in foreign language education in Vietnam nationwide. The first transition from Russian to English teaching that happened at the university in the 1990s reflected language shift at that time in Vietnam. Indeed, before Doi moi, the status of English was still minor, ranking after Russian and French among foreign languages (Le, 2007; Nguyen, 2012; Pham, 2006; Vu \& Burns, 2014; Wright, 2002). Although English had been widely learnt in the 
South of Vietnam where the United States was directly involved in the Vietnam war (19541975), English was still very marginalised in general and particularly in the North of Vietnam (Nguyen \& Nguyen, 2007). Russian was regarded as the most important foreign language in Vietnam for several decades in Vietnam after Independence (1945) and Reunification (1975) (Nguyen, 2012).

In the same vein, the second language shift at the university resonates with the changed position of the English language in national foreign language education since the 1990s. Following the fall of the Soviet Union and the downgrading of Russian, as well as the expansion of the nation's relations to foreign countries and adoption of a marketoriented economy (Nguyen, 2011), English has re-emerged as the main foreign language taught, and has been used in Vietnam for broader communication and cooperation since the 1980s (Alter \& Moreau, 1995; Do, 1999; Wilson, 1993a; 1993b). English then became an attribute for the development of "a better standard of living" (Denham, 1992, p. 64) or an "unquestionable asset" during that time (Shapiro, 1995, p. 4).

Importantly, although two transitions happened at An Nam University, there was no official documentation about these two shifts. In other words, they were implemented as a covert decision, or a de facto or implicit language policy action (Baldauf, 2006; Schiffman, 1996; Shohamy, 2006) of tertiary institutions at the meso-level to require the teachers to transition. As commented by the TTs in their interviews, the idea of transitioning to English teaching was pitched and formed through faculty meetings with faculty and university leaders. It is thus understandable that even though the transition was noted in the literature as a phenomenon (Hoang, Nguyen \& Hoang, 2006; Nguyen,
2011; Nguyen, 2012; Nguyen \& Mai, 2015; Tran, 2015), it was not specifically examined. Arguably, however, there would have been other similar cases and transitions in other contexts nationwide, which were not explored. The examination of the transitions at An Nam University as an example in this study is thus significant to understanding other similar cases, especially in Vietnam and in other Asian countries, in order to potentially take timely action in regards to issues in foreign language education.

Noticeably, as recorded in the document and also in the interview with the faculty leader, the total number of TTs in the faculty used to constitute up to $60 \%$ of the staff and still comprised roughly $50 \%$ at the research time. With such a large proportion of TTs, the covert state of the transitions raised questions about their implementation process as well as their potential influences on foreign language education in the university and in a broader picture in Vietnam, which has not been investigated in previous studies. The next section will present and discuss these impacts.

\subsection{Research question 2: How has the} transition influenced foreign language education in Vietnam?

The transitions at An Nam University had strong influences on general foreign language education in the university and in the Vietnamese contexts. These include longterm teachers' professional development, language retention and language diversity as well as discrepancies between the top-down and grass-roots levels in the language policy implementation process.

\subsubsection{Long-term professional development}

As presented above, the TTs constituted a large number in general human resources at An Nam University and consequently in 
English language education in Vietnam. In line with the overall picture of English teacher education in Vietnam, the transition process has posed the question of long-term effective professional development for these teachers both in their first foreign languages and in English.

First, the transition has led to concerns for the TTs' professional development in English, especially in line with the current required benchmark for English language teachers. Most of the TTs had only had a two-year in-service course in their English language teacher training, which they did not regard highly. These TTs compared their meticulous first foreign language training with the short and ineffective courses in English. In addition, there was a lack of regular effective professional development for these TTs. As many commented, the activities for their professional development were "rare and not effective". After the transition, their English language proficiency was felt to be not progressing.

Even though the majority of the TTs agreed that their English proficiency was adequate for their current teaching of non-major English students, they were not satisfied, nor did they consider themselves as "real" English teachers. TT 1, for example, added that although on the surface he was equipped with adequate degrees, he regarded himself as not meeting the requirements to become an "authentic" English teacher, with knowledge and expertise equal to the other English teachers who majored in English at the beginning. Several TTs also mentioned their wish to have more teaching methodology training. Being TTs, they acknowledged their shortcomings in terms of their English capability.

The TTs' own perceptions of their adequate English ability for their teaching in this study are in part in agreement with Mai (2014). Despite higher requirements from the Ministry of Education and Training (MOET), English teachers in Mai's study and the TTs in this study believed that their current levels were appropriate to be able to teach their students. Additionally, the findings in the current article echo Le (2007) that the retraining for these TTs "was not properly delivered" (p. 172). While Le only mentioned the case of Russian teachers, my study added cases of French and Chinese ones. More importantly, this evidence resonates with other studies about the urgent need for qualified English teachers in Vietnam (Nguyen, 2011) and other Asian countries such as Japan (Butler, 2004) and Taiwan (Tsao, 2008), as well as noting limited proficiency and a lack of understanding of teaching methodology (Carless, 2004; Fung \& Norton, 2002; Hayes, 2008a; Kang, 2008, cited in Nguyen, 2011). Regarding the question of whether the policy will succeed in creating an army of qualified English teachers to cater for the English learning population (Le, 2012; Le \& Do, 2012; Nguyen, 2011, cited in Hamid \& Nguyen, 2016), frequent retraining for these TTs at An Nam University or in a broader landscape in Vietnam can potentially and significantly contribute to such a workforce.

Noticeably, resulting from the transition, issues exist of the TTs' professional development in their first foreign languages. Given the fact that a large group of teachers (TTs 1, 2, 3, 13, 15, 17, 18, 19, 20) still attempted to maintain their first foreign language after the transition, there were no effective activities or a supportive environment for them. They acknowledged that from a sophisticated understanding and high proficiency in their first foreign language at the beginning, since the transition, their first foreign language capacity had been gradually 
weakening. TT 3 said, "I "mai một" [forgot] my first foreign language a lot. I mostly forget my Chinese...". TT 6 also asserted, her first foreign language is "dying, certainly dying itself...". This alarming fact of the loss of first foreign language capability is common among the TTs. Arguably, for these TTs, their English is not better and their first foreign language is dying. This concern was asserted by TT 2, “... Now, Chinese is dying, English is not getting better ... I am not satisfied with myself'. The TTs therefore did not have enough confidence to work in their first foreign language. This has caused problems born out of complex situation in respect of teachers' professional development for both their first foreign language and English.

Overall, a dilemma exists with regard to foreign language teachers' professional development resulting from the language shift. This has raised concerns of unintended consequences in the TTs' professional practices brought about by the transition. One the one hand, the TTs were not satisfied with their English training and their English development without useful courses and activities, which likely caused tensions in their teaching practices. On the other hand, these TTs gradually lost their first foreign language ability. Consequently, the issue of professional development for this group of TTs could affect general foreign language education at the university and the foreign language landscape in Vietnam in general. This converges with other studies in terms of raising significant concerns about teachers' proficiency and satisfaction levels (Mai, 2014; Nguyen, 2011) and teacher training and ongoing professional development in the light of changing expectations of English teachers and teacher roles (Hamid \& Nguyen, 2016). This also raises the need to have government initiatives for teachers' skill enhancement
(Shahab, 2013, cited in Hamid \& Nguyen, 2016). With the distinctive situation of the TTs in this study due to the transition, these considerations are even more significant.

\subsubsection{Language retention and language diversity}

The transition posed questions of language maintenance and language diversity at the university and also in Vietnam. First, with regard to language retention, the TTs have demonstrated their efforts to maintain their first foreign languages despite lack of support. These include teaching, translating and interpreting jobs, being tour guides as well as participating in different social activities or communities related to these languages. Chinese TTs, for example, kept teaching Chinese courses with extra classes or night classes at the language centre and at home. TT 1 revealed that despite currently teaching English, he is still "hoping one day to get back to Chinese", his first foreign language, or to "teach Chinese at the university". TT 1 considered himself as two versions of one person. During the day, he teaches English as "a required, compulsory job", and in the evening, he indulges in his "hobby or as a person of himself" by teaching Chinese. Likewise, teaching French is perceived by many of the French teachers as a "precious treasure" (TT 14) for them to recall good memories. Many of them (TTs 13, 14, 15, $16,17,18,19,20)$ still tried to work with French although these TTs revealed, French classes might have disadvantages such as limited teaching hours and credits compared to English classes. TT 14 admitted,

Teaching [French] means accepting disadvantages, smaller number of students, fewer credits, but everyone loves teaching [French]... teaching a language that we are dedicated to and are passionate with. 
As evidenced from the comments of the TTs, despite the unsupportive environment at An Nam University for foreign languages other than English, the TTs still managed to retain their first foreign languages.

The TTs' attempts with regards to their first foreign language were also shown through my observations during my fieldwork at An Nam University. The French TTs created their own group chat on Zalo. They discussed their teaching on this tool and the other difficulties that they faced in their teaching and tried to find solutions together. This was the space where they could share problems in French teaching, including choosing teaching materials or solving difficulties, if any. These activities and the passion for the languages that the TTs have been working with showed that these TTs have made efforts to retain their first foreign languages. However, many of these activities remain at individual levels.

It is notable that ongoing activities to support these teachers to retain their first foreign languages from the faculty and the university were scarce and ineffective. In terms of administrative and academic management of the French group at the Foreign Languages Faculty, although French was still taught at the Faculty for English-major students, it no longer had either a separate division or a separate leader. In fact, this group belonged to the "Non-major English Division" or so called "English 2" Division. Similarly, the French major also had the same leader who was in charge of the whole "English 2" division and was originally from the Russian major. As TT 20 reported, this division focused more on teaching English for non-major English students, not on French language teaching. There was no one to lead and be officially in charge of the quality of French language teaching. The French TTs therefore had to discuss among themselves if there were any emerging issues with regard to their French teaching. As evident here, compared to English, French is not a focus of language development. The lack of an effective working environment for these languages caused unintended consequences for these TTs regarding working environments and conditions.

Importantly, the TTs' transition to English teaching and the ways of implementing this change has raised issues of language diversity at the university as well as in Vietnam. Due to the lack of support for their first foreign languages, the majority of the TTs gradually ceased their first foreign language teaching which resulted in the downgrading of these languages. The capability and the development of other foreign languages, besides English, at the university will thus be questioned. With respect to general language diversity in Vietnam, only focusing on English at An Nam University seems to be controversial. As asserted by several TTs $(14,15,17,20)$, the maintenance of other languages at the university can have value. TT 17 , for example, explained the reasons to keep French. She argued that students who learn French may not necessarily become French teachers because French is no longer publicly taught at high school, but they still can work in tourism or other fields as interpreters. This fact was shown through the case of TT 15 who still worked successfully as a tour guide in $\mathrm{Sa} \mathrm{Pa}$ besides his teaching at the university during the process of transitioning. The preference for English at the university, which has led to the marginalisation of other languages, thus needs to be considered.

This fact questions Nguyen and Nguyen's (2007) conclusion that English was a compulsory subject in the educational system, but does not deny the opportunity to learn other languages at school. Despite the 
different context (Nguyen and Nguyen's study was at primary level and the current study is at tertiary level), it has been significantly shown in this paper that the preference for English has negatively influenced the development of other foreign languages and has caused the downgrading of language diversity generally. The overemphasis on only one language and neglecting of other foreign languages, as at An Nam University, can lead to an imbalance and a deterioration in language diversity. In addition, as mentioned in "Vietnam adds 5 new foreign languages" (2016), other foreign languages, including Chinese and French, are likely to be added to primary level teaching. The support for and maintenance of these languages thus would probably work as a strategic approach for the long-term development of the university. Supportive actions to maintain these languages are therefore encouraged.

5.2.3. The discrepancies and mismatches between the top-down and grass-roots level

Besides the issues of professional development, language retention and language diversity, the discrepancies and mismatches resulting from the transitions occurring at the university between the top-down and grassroots level are noteworthy.

Firstly, there were mismatches between the leaders' and the teachers' opinions about the reasons leading to the transition. While the transition was considered by the leaders as a matter of fact or the choice of the TTs, the TTs claimed that the transition was a mandatory requirement and was the only choice that they had if they wished to stay working at the university. Given that there was no documentation about the transition, according to the leaders' interviews, the transition was seen as the TTs' only option following the "advice" or "suggestion" of the leaders. The university leaders said,
It is not written, but there were meetings discussing the transitioning demand. They [the TTs] see one thing that the previous generations could overcome the crisis in teaching [the transition], and could stand firmly. Therefore, the next generations also look at the mirror of these ancestors to follow.

Additionally, there existed disparities in the perceptions of the TTs and the university's policy about language diversity. As for applying English as the only foreign language taught at university for non-English major students at the university, both faculty and university leaders gave reasons why the university ended up choosing only English for their foreign language education. The faculty leader noted that there used to be five foreign languages encouraged by the MOET, Chinese, French, Russian, German and English, but "English is the main language taught at the high schools in the region". $\mathrm{He}$ also mentioned that due to the new requirement from the MOET for the standard of students' outcome, if the university had chosen another language, it would be difficult for students to achieve the required standard. The leader of the university added, "the belief of the university's leaders was to follow the trend that English is the global language in the process of globalisation". Obviously, despite being one of the leaders of the university, this leader still mentioned a more powerful figure whose decision was crucial and decisive in this language policy. The notable point is that the TTs had no idea about the meetings, if any, which decided which foreign languages were to be taught. Instead, several of the TTs still believed that students were the ones who did not choose their first foreign languages. This clearly shows the existing gaps and misperceptions in communication between the university leaders and the teachers. 
Controversially, the TTs mentioned their strong opposite view from the leaders' about English choice and the maintenance of language diversity. TT 20, for example, said that the decision to teach English only at the university, for him, was "a wrong decision". He clarified his idea:

I totally do not support this decision because

I think a big university should teach many foreign languages majors, not only English...

Multilateral relations, multiple languages and cultures are very important.

Interestingly, he raised his opinions towards this policy by writing journal articles. He said, his article in a Vietnamese journal about teaching French at universities in Vietnam reflects this point of view, the importance of maintaining different foreign languages at university, rather than just English. He claimed, "maintaining teaching different languages, English, French, Chinese and Russian ensures the diversity of languages, and cultures, and confirm the level of a university". Sharing this opinion, TT 13 thought the decision of the university was too extreme. He said,

[It is] too extreme, too biased towards

English... A university environment should be multi-languages, ....[students] have the right to choose [the foreign language] in schools including university, it is better.

As shown above, these comments exhibit discrepancies in the communication between leaders and teachers about the insights of the transition. This evidence also reveals remaining gaps between the university's policy and the teachers' perceptions in the process of implementing the change at the university. Notably, according to several TTs, there were no forums or opportunities for the TTs to express their "resentments" or opinions on these mismatches. TT 14, for example, said angrily, "No one could respond [to the change]... Teachers had no voice... No one hear [the teachers]..." The decision of the leaders towards policies was perceived as compulsory or "hard to understand" (TT 13). Undoubtedly, these existing discrepancies between leaders' views and the TTs' perceptions and the tensions in teachers' professional practices are unresolved.

The disparities of communication between the leaders and the teachers also led to concerns about general language policy enactment. "Foreign language policy is quite fragile" was the comment of TT 14 after giving examples about different shifts of foreign languages in Vietnam and at An Nam University as well as from his personal experiences. He had specialised in Russian for seven years before he changed to learning and teaching French after the downgrading of Russian in 1990. Recently, with development of English and contraction of French, he transitioned to learning and teaching English. Besides the changes he has made in languages, TT 14 also pointed out an example of this "fragile language policy". He mentioned that Ms Lan [pseudonym] was trained in Russian, but had then just become a ticket seller at the foreign language center of the university due to the diminution of Russian compared to other languages. He also added, "the way of introducing a policy or its implementation,... almost was pre-decided,... nothing to be referenced but have to accept".

The mismatches between topdown and grass-roots levels in this study resonate with results in other studies about language policy implementation, especially the call for more connection between these two levels (Nguyen \& Bui, 2016; Phyak \& Bui, 2014). Different interpretations and meanings of the policy by the teachers have been noted in different studies (Ali, 2013; Zacharias, 2013, cited in Hamid 
\& Nguyen, 2016). Indeed, the connection and communication between the teachers who directly enact the policy, and the stakeholders or the leaders who draft the policy, should be more effectively conducted. The gap in communication between these two actors as shown in this study could lead to inefficacy of the enactment process. In other words, in response to the current promulgation of policies in Vietnam, for better understanding and communication in the policy enactment process, these gaps and disparities between the top-down and the reality at grass-roots level deserve more attention in some contexts in Vietnam (Nguyen \& Bui, 2016).

\section{Conclusion}

The article has discussed the transitions to English teaching from other languages in An Nam University in line with general language shifts in foreign language education in Vietnam. Issues of professional development, language retention, language diversity and the connection between the top-down and grassroots level in language policy implementation were noted as influences of this process on and considerations for general foreign language education and language planning. The transition that happened at the university was a covert solution of the university in response to educational changes in Vietnam, which had resulted from socio-cultural and economic contexts in the country. It is arguable that there would be other cases or universities in Vietnam which have not been investigated. However, the covert process of implementing the change at An Nam University created problems for the ongoing necessary actions to respond to it, as well as how to balance and reconcile the transition with the current policy enactment in the country. As presented, even though the university has made efforts to maintain appropriate human resources and to partly solve the problems of the language shift, major issues exist. These include how to manage and maintain professional development for this group and their engagement with the new field of teaching, and how this transition process has directed and affected foreign language education in the university. These are several of the many questions discussed in the article and to be further addressed for other contexts in Vietnam and in other countries undergoing similar changes.

With the impact from the whole country's history and general education, the actions for the transition process should not be limited to a university level, but significantly at national level and include the stakeholders of the country. Looking back at the transition or the remnants of previous language education policy as a strategy to strengthen current and future foreign language education is laudable and should be encouraged. The inadequacy of macro-level policies and the lack of support for teachers that would equip them linguistically and pedagogically for developing students' proficiency in English was noted (Hamid \& Nguyen, 2016) and emphasised in this study. Importantly, the connection between the university leaders and the teachers or between the stakeholders of policy making and the institutions was seen as the key issue to bridge the gap. Concerns of the TTs as presented in the study can only be solved when these are voiced by the stakeholders such as university's leaders and policy makers. Hamid and Nguyen (2016) emphasised that "if English language policies have produced only modest outcomes in many of the Asian societies, it is largely due to teachers and teacher education and professional development issues" (p. 37). Employing a case study approach, this paper acknowledges its limitation on the study's generalisability stemming from the 
exploration of only one university in Vietnam. Nevertheless, its theoretical framework and employed methodology can be applicable to other situations in which the findings in this article can be reinterpreted. Further considerations and actions for this group of TTs and the transition process in other contexts or institutions in Vietnam and in other contexts experiencing similar language shifts are thus recommended.

\section{References}

\section{Vietnamese}

Hoàng Văn Vân, Nguyễn Thị Chi, Hoàng Thị Xuân Hoa (2006). Đổi móri phuoong pháp dạy tiếng Anh ở trung hoc phổ thông Việt Nam. Hà Nội: Nxb. Giáo dục.

\section{English}

Alter, J. \& Moreau, R. (1995). Binding up old wounds. Newsweek, 33-34.

Baldauf, R. B. (2006). Rearticulating the case for micro language planning in a language ecology context. Current Issues in Language Planning, 7(2), 147170.

Baldauf, R. B. (2012). Introduction - Language planning: Where have we been? Where might we be going? Revista Brasileira de Linguística Aplicada, 12(2), 233-248. doi: 10.1590/S1984-63982012000200002

Ball, S. J. (1994). Education reform: A critical and poststructural approach. Buckingham: Open University Press.

Ball, S. J. (2015). What is policy? 21 years later: Reflections on the possibilities of policy research. Discourse: Studies in the Cultural Politics of Education, 36(3), 306-313. doi: 10.1080/01596306.2015.1015279

Ball, S. J., Maguire, M., \& Braun, A. (2012). How schools do policy. Policy enactments in secondary schools. London: Routledge.

Bowe, R., Ball, S., \& Gold, A. (1992). Reforming education and changing schools: Case studies in policy sociology. London: Routledge.

Butler, Y. G. (2004). What level of English proficiency do elementary school teachers need to attain to teach EFL? Case studies from Korea, Taiwan, and Japan. TESOL Quarterly, 38, 245-278.

Campbell, E. (2012). Teacher agency in curriculum contexts. Curriculum Inquiry, 42(2), 184-190.

Datnow, A. (2012). Teacher agency in educational reform: Lessons from social networks research. American Journal of Education, 119(1), 193-201. doi: $10.1086 / 667708$.

Denham, P. (1992). English in Vietnam. World Englishes, 11(1), 61-69.

Do, H. T. (1999). Foreign language education policy in Vietnam: The emergence of English its impact on higher education. Paper presented at the In Partnership and Interaction: Proceedings of the Fourth International Conference on Language and Development, Hanoi, Vietnam.

Franzosi, R. (2004). From words to numbers: Narrative, data, and social science. Cambridge: Cambridge University Press.

Glesne, C. (2006). Becoming qualitative researcher: An introduction (3rd ed.). Boston, MA: Pearson.

Gornitzka, A., Kogan, M., \& Amaral, A. (2005). Reform and change in higher education. Analysing policy implementation. Dordrecht: Springer.

Kaplan, R. B., \& Baldauf, R. B. Jr. (1997). Language planning: From practice to theory. Clevedon, UK: Multilingual Matters.

Hamid, M. O., \& Nguyen, H. T. M. (2016). Globalization, English language policy, and teacher agency: Focus on Asia. International Education Journal: Comparative Perspectives, 15(1), 26-43.

Heimans, S. (2014.) Education policy enactment research: Disrupting continuities. Discourse: Studies in the Cultural Politics of Education, 35(2), 307-316. doi: 10.1080/01596306.2013.832566

Kaplan, R. B., \& Baldauf, R. B. Jr. (1997). Language planning: From practice to theory. Clevedon, UK: Multilingual Matters.

Le, V. C. (2007). A historical review of English language education in Vietnam. In Y. H. Choi \& B.Spolsky (Eds.), English education in Asia: History and politics (pp. 168-180). Seoul, Korea: Asia TEFL.

Liddicoat, A. J., \& Baldauf, R. B. (2008). Language planning in local contexts: Agents, contexts and interactions. In A. J. Liddicoat \& R. B. Baldauf (Eds.), Language Planning in Local Contexts (pp. 3-17). Clevedon: Multilingual Matters.

Mai, N. K. (2014). Towards a holistic approach to developing the language proficiency of Vietnamese primary teachers of English. Electronic Journal of Foreign Language Teaching, 11(2), 341-357.

Merriam, S. B. (1998). Qualitative research and case study applications in education. San Francisco, CA: Jossey-Bass.

Nguyen, N. (2012). How English has displaced Russian and other foreign languages in Vietnam since "Doi Moi”. International Journal of Humanities and Social Science, 2(23), 259-266.

Nguyen, T. M. H. (2011). Primary English 
language education policy in Vietnam: Insights from implementation. Current Issues in Language Planning, 12(2), 225-249. doi: 10.1080/14664208.2011.597048

Nguyen, T. M. H., \& Bui, T. (2016). Teachers' agency and the enactment of educational reform in Vietnam. Current Issues in Language Planning, 17(1), 88105. doi: 10.1080/14664208.2016.1125664

Nguyen, T. M. H., \& Nguyen, Q. T. (2007) Teaching English in primary schools in Vietnam: An overview. Current Issues in Language Planning, 8 (2), 162173. doi: $10.2167 /$ cilp106.0

Nguyen, T. N. (2011). West wind blows: Voices of Vietnamese teachers and students of English - A case study of Nha Trang University. (PhD), Ohio University.

Nguyen, V. T., \& Mai, N. K. (2015). Responses to a language policy: EFL teachers' voices. The European Journal of Social \& Behavioural Sciences, 13(2), 1830.

Ollerhead, S., \& Ollerhead, S. (2010). Teacher agency and policy response in the adult ESL literacy classroom. TESOL Quarterly, 44(3), 606-618. doi:10.5054/tq.2010.230742_1

Ozga, J. (2000). Policy research in educational settings: Contested terrain. Buckingham: Open University Press.

Pham, H. H. (2006). Reaching the research culture in English language education in Vietnam. Teaching English as a Second or Foreign Language, 10(2), 1-20.

Phyak, P., \& Bui, T. (2014). Youth engaging language policy: Ideologies and transformations from within. Language Policy, 13(2), 101-20.

Priestley, M., Edwards, R., Priestley, A. \& Miller, K. (2012). Teacher agency in curriculum making: Agents of change and spaces for manoeuvre. Curriculum Inquiry, 42(2), 191-214.

Reynolds, J., \& Saunders, M. (1987). Teacher responses to curriculum policy: Beyond the 'Delivery' metaphor. In J. Calderhead (Ed.), Exploring teachers' thinking (pp. 195-214). London: Cassell Educational Limited.

Schiffman, H. (2006). Language policy and linguistic culture. In T. Ricento (Ed.), An introduction to language policy: Theory and method (pp. 111-126). Malden: Blackwell Publishing.

Shapiro, L. (1995). English language training in Vietnam in the era of Doi Moi: Ho Chi Minh City: A descriptive case study. (Master's thesis, The School for International Training Brattleboro, Vermont). Retrieved from ERIC database. (ED418605)

Shohamy, E. (2006). Language policy: Hidden agendas and new approaches. London and New York: Routledge.

Sin, C. (2014). The policy object: A different perspective on policy enactment in higher education. Higher Education, 68(3), 435-448. doi:10.1007/s10734-014-9721-5

Singh, P., Thomas, S. \& Harris, J. (2013).
Recontextualising policy discourses: A Bernsteinian perspective on policy interpretation, translation, enactment. Journal of Education Policy, 28(4), 465480. doi: 10.1080/02680939.2013.770554

Stake, R. E. (1995). The art of case study research. Thousand Oaks: Sage Publications.

Tran, T. H. (2015). Higher education and globalisation: A case of Vinh University, Vietnam. Journal of Science, Vinh University, 44(2B), 14-26.

Trowler, P. (2002). Higher education policy and institutional change: Intentions and outcomes in turbulent environments. Buckingham: Society for Research into Higher Education \& Open University Press.

Trowler, P., Saunders, M., \& Knight, P. (2004). Change thinking, change practices. A guide to change for heads of department, subject centres and others who work middle-out. Paper written with support from: The LTSN Generic Centre, The UK Evaluation of the LTSN and The HEFCE Innovations project "Skills plus".

Tsao, F.-F. (2008). The language planning situation in Taiwan. In R.B. Kaplan \& R.B. Baldauf, Jr. (Eds.), Language Planning and Policy in Asia, Vol.1: Japan, Nepal and Taiwan and Chinese Characters (pp. 285-300). Bristol: Multilingual Matters.

Unluer, S. (2012). Being an insider researcher while conducting case study research. The Qualitative Report, 17(29), 1.

Vähäsantanen, K. (2015). Professional agency in the stream of change: Understanding educational change and teachers' professional identities. Teaching and Teacher Education, 47, 1-12. doi: 10.1016/j. tate.2014.11.006

Vietnam adds 5 foreign languages to controversial primary syllabus (2016, Sep 16), Saigoneer. Retrieved from https://saigoneer.com/vietnam-news

Vu, N., \& Burns, A. (2014). English as a medium of instruction: Challenges for Vietnamese tertiary lecturers. The Journal of Asia TEFL, 11(3), 1-31.

Weber, R. P. (1990). Basic content analysis (2nd ed.). Newbury Park, CA: Sage.

Wilson, C. (1993a). Education in Hanoi. TESOL Matters, 3(4), 16.

Wilson, C. (1993b). Education in Ho Chi Minh City. TESOL Matters, 3(5), 16.

Wright, S. (2002). Language education and foreign relations in Vietnam. In J. Tollefson (Ed.), Language Policies in Education: Critical Issues (pp. 225-244). Mahwah: Lawrence Erlbaum.

Yin, R. K. (1984). Case study research: Design and methods (Vol. 5). Beverly Hills, Calif: Sage Publications. 


\title{
QUÁ TRİNH CHUYỂN ĐỔI SANG GIẢNG DẠY TIẾNG ANH: NHỮNG ẢNH HƯỞNG VÀ XEM XÉT TRONG GIÁO DỤC VÀ CHÍNH SÁCH NGOẠI NGỮ NÓI CHUNG
}

\author{
Trần Thị Hảo \\ Trưòng Đại học Griffith, 170 Kessels Rd, Queensland, Australia
}

Tóm tắt: Quy trình ban hành chính sách ngôn ngữ là quá trình rất phức tạp, bị chi phối và định hình bởi các tác động, diễn giải, đàm phán và thỏa hiệp khác nhau. Dựa trên góc độ xem xét này, bài viết tìm hiểu quá trình chuyển đổi của các giáo viên dạy các ngôn ngữ khác sang giảng dạy tiếng Anh, cũng như những ảnh hưởng của nó đối với giáo dục và chính sách ngoại ngữ nói chung. Mặc dù ở Việt Nam, việc chuyển đổi sang dạy tiếng Anh từ các ngôn ngữ khác đã được ghi nhận là một hiện tượng nhưng những thay đổi và ảnh hưởng của nó đến các chính sách ngoại ngữ trong nước chưa được nghiên cứu một cách cụ thể. Thông qua phương pháp nghiên cứu tình huống, bài viết tìm hiểu quá trình chuyển đổi diễn ra tại Đại học An Nam (tên truoòng do tác giả tụ đặt), một trong những trường đại học sớm trải qua quá trình chuyển đổi này. Thông qua phân tích tài liệu, phiếu điều tra, phỏng vấn với giáo viên tham gia chuyển đổi và lãnh đạo của khoa và trường, cũng như sự quan sát của tác giả, bài báo đã đưa ra kết luận về vai trò và những ảnh hưởng của quá trình chuyển đổi đối với các khía cạnh khác nhau trong giáo dục ngoại ngữ ở trường hợp được nghiên cứu và ở Việt Nam. Bài viết cũng đề xuất một số gợi ý cơ bản đối với việc thực hiện chính sách ngôn ngữ trong nước cũng như ở các bối cảnh nghiên cứu khác có trải qua sự thay đổi tương tự.

Tù khóa: giáo dục ngoại ngữ, chuyển đổi, Việt Nam, giáo viên tiếng Anh, chính sách ngoại ngữ 